Vol.45, N. 2 : pp. 203 - 207, June 2002

ISSN 1516-8913 Printed in Brazil

BRAZILIAN ARCHIVES OF BIOLOGY AND TECHNOLOGY

AN INTERNATIONAL JOURNAL

\title{
Rheumatoid Factor And Tobacco Exposure
}

\author{
Thelma Larocca Skare*; Marilia Barreto Gameiro Silva; Mônica Gomes da Silva; Fábio \\ Gomes; Carla Rumor and Glaucio Giacomini \\ Faculdade Evangélica de Medicina do Paraná; Rua João Alencar Guimarães, 796; CEP 80310-420; Curitiba - PR
}

\begin{abstract}
This study was carried out to analyse the possible influence of smoking on the positivity of rheumatoid factor (RF) in healthy individuals in the region of Curitiba, Brazil. One hundred fifty blood donors (84 smokers and 66 nonsmokers ) were studied for the presence of RF using nephelometry. Smoking was found not to be correlated to the positivity of $R F$, independently of the smokers sex (men with $p=0.09$ and women with $p=0.49$ ), the number of cigarettes/day $(p=0.20)$, duration of smoking $(p=0.18)$ and cumulative exposure (time $X$ quantity) to cigarettes $(p=0.13)$.
\end{abstract}

Key words: Rheumatoid factor, smoking, rheumatoid arthritis, tobacco exposure

\section{INTRODUCTION}

Smoking is probably the largest potentially reversible risk factor to public health and thus deserving considerable attention by researchers. Though its effects on respiratory and vascular diseases are widely known by the medical community, little is known about its possible influence on rheumatic diseases such as rheumatoid arthritis (RA). According to Silman (1993), lack of knowledge might come from the fact that rheumatoid arthritis is mostly a female disease, while the habit of smoking has been, until recently, mostly masculine. Besides that the incidence of rheumatoid arthritis tends to stay relatively the same in developed countries with very little geographical variation, while the smoking habits are highly variable (Silman, 1993). The etiology of rheumatoid arthritis is unknown, but the influence of both genetical and environmental factors seems to exist.
The rheumatoid factor (RF) is an antibody directed against the $\mathrm{Fc}$ fraction of immunoglobulin $\mathrm{G}$ and is considered a marker of rheumatoid arthritis (Firestein, 1997). However, this autoantibody can appear in healthy population, some of which will develop later the clinical disease. (Mac Gregor \& Silman, 1991; Aho et al, 1991). According to Del Puente et al. (1988), the presence of RF in a healthy person poses a risk that the person may develop the disease later on, especially if the test stays positive throughout the period.

Generally presence of RF is associated with exposure to certain air pollutants. The Caplan syndrome is a special form of RA, which affects individuals with pneumoconiosis and tends to present itself with several lung nodules and high titers of RF (Harris Jr, 1997). A higher incidence of RA in individuals exposed to silica has also been described (Klockars et al, 1987).

Thus two questions can be made: is the smoking habit linked to the appearence of RF? And if this

\footnotetext{
* Author for correspondence
} 
association between smoking and RF exists would these individuals suffer from a higher incidence of rheumatoid arthritis?

The few studies conducted until now have shown controversial results. A population survey in Australia showed that young smokers were at increased risk of being positive for RF (Mathews et al, 1973). The same was found by a group of Finnish researchers which stressed that this positivity was stronger in young males (Heliövaara et al, 1993). Hazes et al (1990) found that smoking (more than 1 cigarret/day) had a protective effect against RA, but this protection was lost with higher exposure (>21 cigarrets/day). These controversy motivated us to study the subject.

\section{MATERIAL AND METHODS}

One hundred and fifty healthy blood donnors were studied; 70 were women and 80 men, aging between 19 and 59 years. A questionnaire was made related to smoking habit and blood samples were taken to study the serum for the presence of RF by nephelometry (BANDILLA \& McDuffie, 1969). Samples with $40 \mathrm{UI} / \mathrm{ml}$ or more were considered positive.

Age distribution is shown in Table 1.

Table 1 - Age distribution of studied population

\begin{tabular}{ccc}
\hline AGE & FREQUENCY & $\%$ \\
\hline Until 19 years & $\mathrm{n}=11$ & 7.33 \\
20 to 29 years & $\mathrm{n}=61$ & 40.67 \\
30 to 39 years & $\mathrm{n}=42$ & 28.00 \\
40 to 49 years & $\mathrm{n}=28$ & 18.67 \\
50 to 59 years & $\mathrm{n}=08$ & 5.33 \\
Total & $\mathrm{n}=150$ & 100 \\
\hline
\end{tabular}

$\mathrm{n}=$ number
Of these 150 individuals: 66 had never smoked (30 men and 36 women) and 84 had the habit of smoking (50 men and 34 women). The daily smoking habits of studied population is summarized in Table 2. The duration of smoking is shown in Table 3.

The data collected were submitted to statistical treatment using the di square test, Fisher's test and linear regression adjustment.

Table 2 - Daily smoking habits of studied population

\begin{tabular}{ll}
\hline Never smoked & $\mathrm{n}=66(44 \%)$ \\
\hline$<10$ cigarretes/day & $\mathrm{n}=39(26 \%)$ \\
10 to19 cigarretes/day & $\mathrm{n}=23(15,33 \%)$ \\
$>20$ cigarretes/day & $\mathrm{n}=22(14.67 \%)$ \\
TOTAL & $\mathrm{n}=150(100 \%)$ \\
$\mathrm{n}=$ number & \\
\hline
\end{tabular}

Table 3 - Smoking duration of studied population

\begin{tabular}{ll}
\hline 1 year or less & $\mathrm{n}=10(11.9 \%)$ \\
1 to 3 years & $\mathrm{n}=9(10.71 \%)$ \\
4 to 5years & $\mathrm{n}=9(10.71 \%)$ \\
6 to 10 years & $\mathrm{n}=19(22.62 \%)$ \\
11-20years & $\mathrm{n}=25(29.76 \%)$ \\
$>20$ years & $\mathrm{n}=12(14.29 \%)$ \\
TOTAL & $\mathrm{n}=84(100 \%)$ \\
\hline
\end{tabular}

$\mathrm{n}=$ number

\section{RESULTS}

In the studied sample, $70 \%$ of the individuals $(n=105)$ had a negative RF and $30 \%(n=45)$ had a positive one. The positive tests were weakly reactive, the maximum titer being 79,21 UI. RF was positive in 20 of 84 smokers $(23.80 \%)$ and in 25 of 66 non smokers (37.87\%). The results can be seen in table 4.

Table 4 - RF positivity according to the gender and smoking habits

\begin{tabular}{|c|c|c|c|c|c|}
\hline & \multicolumn{2}{|c|}{ RF positive } & \multicolumn{2}{|c|}{ RF negative } & Total \\
\hline Blood donnors & Smoker & Non smoker & Smoker & Non smoker & \\
\hline $\begin{array}{l}\text { Female } \\
\text { Male }\end{array}$ & $\mathrm{n}=10$ & $\begin{array}{l}n=13 \\
n=12\end{array}$ & $\begin{array}{l}n=24 \\
n=18\end{array}$ & $\begin{array}{l}\mathrm{n}=23 \\
\mathrm{n}=40\end{array}$ & $\begin{array}{l}n=70 \\
n=80\end{array}$ \\
\hline Male & $n=10$ & $\mathrm{n}=12$ & $\mathrm{n}=18$ & $\mathrm{n}=40$ & $n=80$ \\
\hline
\end{tabular}

$\mathrm{n}=$ number

When the results of RF were analyzed in relation to the quantity of cigarettes/day through the chi square test, no relation between the amount of daily exposure to smoking and positivity of RF was found $(p=0.20)$, neither for women $(p=0.49)$ nor for men $(p=0.09)$. Positivity of RF in relation to time of smoking was analysed through linear regression adjustment and no association was found $(\mathrm{p}=0.18)$. Figure 1 . 


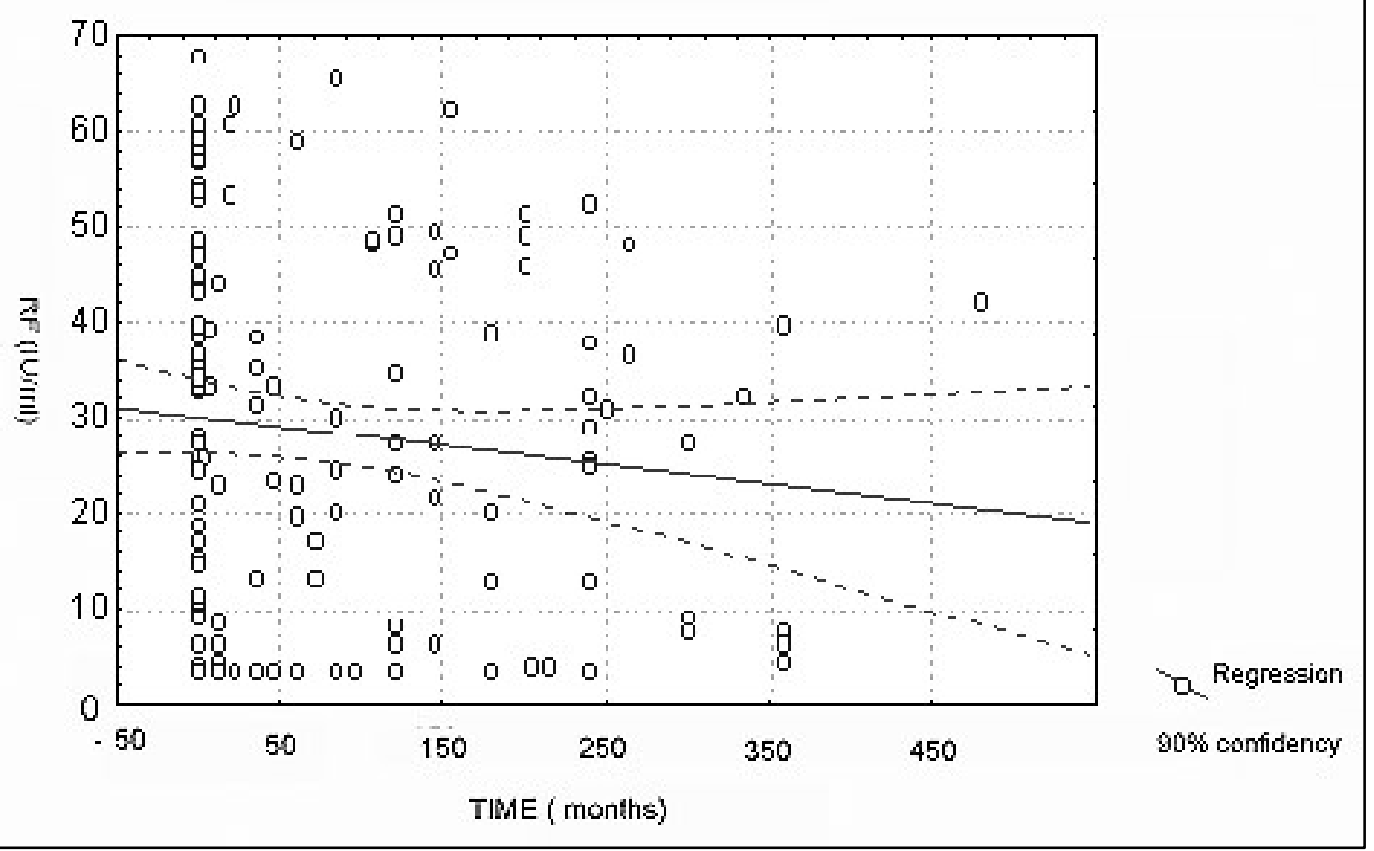

Figure 1 - Correlation between smoking time and RF. According to the linear regression adjustment, no correlation was found between total smoking time and RF positivity ( $r=-0.1095$ ).

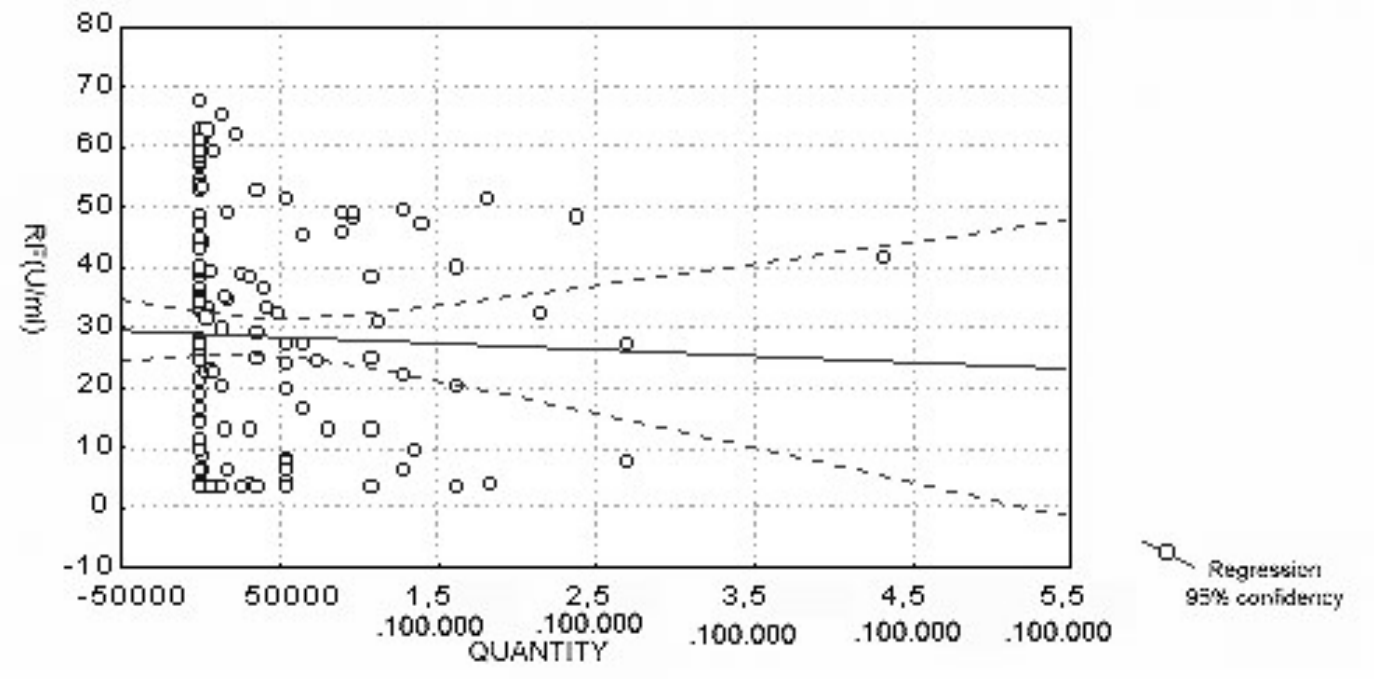

Figure 2 - Correlation between total quantity of cigarrets and RF. According to the linear regression adjustment, no correlation was found between total quantity of cigarrets and RF positivity ( $r=-$ 0.359 ). 
To find out verify if there was a relation between the total quantity of consumed cigarettes (time $\mathrm{X}$ daily quantity) and the presence of RF, an increasing percentage of weakly positive cases were found when more cigarettes were consumed. However, this increase was not deemed relevant by chi square test $(\mathrm{p}=0.13)$. Figure 2 .

Otherwise no evidence was found that could implicate an association between smoking, RF and the age of the smoker (Fisher's test, $\mathrm{p}=0.26$ ).

\section{DISCUSSION}

According to Saag et al. (1997), smoking is associated with the occurence of leucocytosis and heavy smokers have abnormalities in their $\mathrm{T}$ lymphocytes which is something that could predispose them to immunological abnormalities. Once rheumatoid arthritis appears, it is more aggressive in smokers than in non-smokers. Another study, conducted with monozygotic and dizygotic twins, showed that smoking increased the susceptibility to RA (Silman et al, 1996). A survey carried out in large scale in Finland found that healthy smokers had a higher incidence of RF than non-smokers, and that the exposure of men to cigarette favored the appearence of clinical disease ( Heliövaara et al, 1995).

Masi et al.(1998) found that smoking had a hazardous effect on RA but this finding appeared not to depend on a higher production of RF. It could be explained by an increase in the endothelial damage, because of alterations in the metabolism of nitric oxide, which would predispose to vasculitis .

However, not all authors attribute a deleterious effect to smoking in RA. Hazes et al. (1990), considering the low number of smokers in patients with RA, postulated that smoking could have a defensive effect against this disease. According to Silman (1993), smoking caused depletion of antigen presenting cells, which could reduce the risk of chronic inflammatory processes, as already demonstrated in cases of ulcerative colitis. Since smoking has anti-estrogenic effects, it could protect against diseases in which estrogen act as an immunomodulator .

Thus, there are arguments favoring both sides of the debate. One must keep in mind that RF positivity suffers genetic influence which can explain different results in populations of different genetic background.
In the present study, no relation could be found demonstrating this association either according to daily exposure, or related to cumulative exposure to smoking. It can be concluded that $27 \%$ of the studied population made up of healthy individuals between 19 and 59 years was positive for RF and no association between this positivity and the habit of smoking could be found.

\section{ACKNOWLEGMENTS}

We thank to GR Laboratory- Curitiba, Brazil, for the technical support.

\section{RESUMO}

Os estudos sobre a influência do fumo na artrite reumatóide (AR) são contraditórios. Esta pesquisa foi feita com a finalidade de se analisar a possível influência do tabagismo sobre a positividade do fator reumatóide (FR) em indivíduos saudáveis da região de Curitiba, PR. Foram estudados 150 doadores de sangue (84 fumantes e 66 não fumantes) para a presença do FR através do teste de nefelometria. Encontrou-se que 105 indivíduos eram negativos para o FR e 45 eram positivas.

$\mathrm{O}$ hábito de fumar não se correlacionou com a positividade do FR, independentemente do sexo do fumante (homens com $\mathrm{p}=0,09$ e mulheres com $\mathrm{p}=0,49)$, do número de cigarros/dia $(\mathrm{p}=0,20)$, do tempo de fumo $(\mathrm{p}=0,18)$ e da exposição cumulativa (tempo $\mathrm{X}$ quantidade) ao cigarro $(\mathrm{p}=0,13)$.

\section{REFERENCES}

Aho, K.; Heliövaara, M.; Maatela, J., Tuomi, T. and Polosuo, T. (1991), Rheumatoid factors antedating clinical rheumatoid arthritis. J. Rheumatol., 18 : (9), 1282-1284.

Bandilla, K. I. and McDuffie, F. C. (1969), Reactivity of rheumatoid factor with autologous IgG antibodies. Arthritis and Rheum, 12, 74-81.

Del Puente, A.; Knowler, W.C.; Pettitt, D. J. and Bennett, P. H. (1988), The incidence of rheumatoid arthritis is predicted by rheumatoid factor in a longitudinal populacional study. Arthritis \& Rheum, 31 : (10), 1239-1244. 
Firestein, G. (1997), Etiology and pathogenesis of rheumatoid arthritis. In - Kelley et al. Textbook of Rheumatology, $5^{\text {th }}$ ed., W.B.Saunders Co, Philadelphia, 851-897.

Harris Jr., E. (1997), Clinical features of rheumatoid arthritis. In - Kelley et al. Textbook of Rheumatology. $5^{\text {th }}$ ed. W.B.Saunders Co, Philadelphia, 898-932.

Hazes, J. M. W.; Dijkmans, B. A. C.; Vandenbroucke, J. P.; de Vries, R. R. P. and Cats, A. (1990), Lifestyle and the risk of rheumatoid arthritis: cigarette smoking and alcohol consumption. Ann. Rheum. Dis., 49, 980-982.

Heliövaara, M.; Aho, K.; Aromaa, A.; Knekt, P. and Reunanen, A. (1993), Smoking and risk of rheumatoid arthritis. Journal of Rheumatology, 20 : (11), 1830-1835.

Klockars, M.; Koskela, R. S.; Järvinen, E.; Kolari, P. J. and Rossi, A. (1987), Silica exposure and rheumatoid arthritis: a follow up study of granite workers 1940-1981. Br. Med. J., 294, 997-1000.

MacGregor, A. J. and Silmann, A. J. (1991), Rheumatoid factors as predictors of rheumatoid arthritis. J. Rheumatol., 18 : (9), 1280-1281.
Masi, A. T.; Aldag, J. C.; Malamet, R. L. and Hazes, J. M. W. (1998), Smoking and rheumatoid arthritis. Arthritis \& Rheum., 41 : (1), 184-185.

Mathews, J. D.; Whittingham, S.; Hooper, B. M. and Mackay, J. R. (1973), Association of autoantibodies with smoking, cardiovascular morbidity and death in the Busselton population. Lancet, 2, 753-756.

Saag, K. G.; Cerhan, J. R.; Kolluri, S.; Ohashi, K.; Hunninghake, G. W. and Schwartz, D. A. (1997), Cigarette smoking and rheumatoid arthritis severity. Ann. Rheum. Dis., 56, 463-369.

Silman, A. (1993), Smoking and the risk of rheumatoid arthritis. J. Rheumatol., 20 : (11), 1815-1816.

Silman, A.; Newman, J. and MacGregor, A. J. (1996), Cigarette smoking increases the risk of rheumatoid arthritis. Arthritis \& Rheum., 39 : (5), 732-735.

Received: June 07, 2000; Revised: December 27, 2000; Accepted: January 29, 2001, 


\title{
PÁGINA
}

\author{
EM
}

BRANCO 